\title{
Exposure to Traffic-Related Particulate Matter 2.5 Triggers Th2-Dominant Ocular Immune Response in a Murine Model
}

\author{
Hyun Soo Lee ${ }^{1, *}$, Sehyun Han ${ }^{2}$, Jeong-Won Seo ${ }^{3}$ and Ki-Joon Jeon ${ }^{2}$ \\ 1 Department of Ophthalmology, Eunpyeong St. Mary's Hospital, College of Medicine, \\ The Catholic University of Korea, Seoul 03312, Korea \\ 2 Department of Environmental Engineering, Inha University, Incheon 22212, Korea; \\ shhaninhauniv@gmail.com (S.H.); kjjeoninha@gmail.com (K.-J.J.) \\ 3 Department of Ophthalmology, Hallym University Dongtan Sacred Heart Hospital, College of Medicine, \\ Hallym University, Gyeonggi-do 18450, Korea; jwseohallym@gmail.com \\ * Correspondence: cotranmd@gmail.com; Tel.: +82-2-2258-6861; Fax: +82-2-533-3801
}

Received: 27 March 2020; Accepted: 20 April 2020; Published: 24 April 2020

\begin{abstract}
Ambient particulate matter (PM), a major component of air pollution, aggravates ocular discomfort and inflammation, similarly to dry eye disease (DED) or allergies. However, the mechanism(s) by which PM induces the ocular inflammatory response is unknown. This study investigated the immunological response of traffic-related fine particulate matter $\left(\mathrm{PM}_{2.5}\right)$ on the ocular surface in a murine model. C57BL/6 mice were exposed by topical application to $\mathrm{PM}_{2.5}$ or vehicle for 14 days to induce experimental environmental ocular disease. Corneal fluorescein staining and the number of ocular inflammatory cells were assessed in both groups. The expression of IL-1 $\beta$, IL-6, tumor necrosis factor (TNF)- $\alpha$, and mucin 5AC (MUC5AC) in the ocular surface were evaluated by real-time PCR. An immunohistochemical assay evaluated apoptosis and goblet cell density. ELISA was used to determine the levels of serum IgE and cytokines of Type 1 helper (Th1) and Type 2 helper (Th2) cells after in vitro stimulation of T cells in the draining lymph nodes (LNs). Exposure to traffic-related $\mathrm{PM}_{2.5}$ significantly increased corneal fluorescein staining and cellular toxicity in the corneal epithelium compared with the vehicle control. A significant increase in the number of $\mathrm{CD} 11 \mathrm{~b}+$ cells on the central cornea and mast cells in the conjunctiva was observed in the $\mathrm{PM}_{2.5}$ group. Exposure to $\mathrm{PM}_{2.5}$ was associated with a significant increase in the corneal or conjunctival expression of IL-1 $\beta$, IL-6, TNF, and MUC5AC compared to the vehicle, and increased maturation of dendric cells (DCs) (MHC-II ${ }^{\text {high }} \mathrm{CD} 11 \mathrm{c}^{+}$) in draining LNs. In addition, $\mathrm{PM}_{2.5}$ exposure increased the level of serum IgE and Th2 cytokine production in draining LNs on day 14. In conclusion, exposure to traffic-related $\mathrm{PM}_{2.5}$ caused ocular surface damage and inflammation, which induced DC maturation and the Th2-cell-dominant allergic immune response in draining LNs.
\end{abstract}

Keywords: air pollution; allergic conjunctivitis; dendritic cell (DC); dry eye disease (DED); particulate matter (PM)

\section{Introduction}

Due to industrialization, air pollution has gained attention as a major risk factor for respiratory and cardiovascular diseases, with increased morbidity and mortality worldwide [1-3]. With continued urbanization, air-pollution-related health problems are expected to worsen with time [1,2]. Sources of air pollution include combustion of wood and fossil fuels, road transport, and building construction, which can be organized into carbon, heavy metals, nitrates, sulfates, ozone, polycyclic aromatic hydrocarbons, and toxic pollutants. These air pollutants vary by size, composition, and source [3-5]. 
Particulate matter (PM) is one of the major components of air pollution, and is used to indicate the severity of air pollution [5,6]. Recent studies have focused on fine particles $\left(\mathrm{PM}_{2.5}\right.$; particulate matter less than $2.5 \mu \mathrm{m}$ in aerodynamic diameter) in air pollution, which are more likely to have adverse medical effects than larger particles [6,7]. $\mathrm{PM}_{2.5}$ is harmful to the respiratory and cardiovascular systems, causing asthma, vascular ischemia, and thrombosis [4-7].

The eyes are very sensitive to environmental agents because they are protected from harmful matter by only a thin layer of tear film [8]. Various studies suggest that air pollution could cause ocular irritation and subclinical inflammation, which is associated with dry eye disease (DED) or allergic conjunctivitis [9-12]. Recently, studies on the correlation between ocular symptoms and levels of PM have been gaining attention [9-11]. However, the mechanisms by which PM affects the eyes have not been sufficiently elucidated. Most research has investigated the influence of diesel exhaust particles or titanium dioxide on eye disease [13-15], which does not accurately reflect the characteristics of PM in the eyes. Therefore, it is necessary to conduct research on the effects of PM in the eyes and ocular diseases using traffic-related PM from actual road dust. Research by Karagulian et al. found that $25 \%$ of ambient PM was from traffic, more than industry, domestic fuel burning, and undetermined sources of human origin [16]. The main sources of traffic-derived $\mathrm{PM}_{2.5}$ were engine emissions, road dust, and tire wear $[9,16]$.

However, although air pollution, including PM, is associated with ocular diseases such as dry eye and conjunctivitis, the mechanism by which traffic-related $\mathrm{PM}_{2.5}$ causes environmental ocular disease has not been extensively studied $[9,17,18]$. Therefore, we used traffic-related $\mathrm{PM}_{2.5}$ collected from road dust to determine how PM alters the immune response in the healthy mice.

\section{Materials and Methods}

\subsection{Animals}

Eight to nine week old male C57BL/6 mice (Charles River Laboratories, Orient Co., Sungnam, Korea) were housed in pathogen-free conditions at the Catholic Medical Institute Animal Care Facility. All procedures and protocols (ethical code: 2019-0261-01) were approved by the Catholic Medical Research Institute Animal Care and Use Committee, and all animals were treated according to the Statement for the Use of Animals in Ophthalmic and Visual Research (ARVO). Mice received a topical application of $4 \mu \mathrm{L}$ of $0.5 \mathrm{mg} / \mathrm{mL}$ traffic-related $\mathrm{PM}_{2.5}$ twice daily for 14 days. Age- and sex-matched mice were used as the normal controls. After 14 days, ocular injury was evaluated by corneal fluorescein staining. First, $1 \mu \mathrm{L}$ of $1 \%$ fluorescein (Sigma-Aldrich) was administrated to the inferior-lateral conjunctival sac of the eye. After three minutes, corneal fluorescein staining was evaluated using a slit lamp biomicroscope. Punctate corneal staining was calculated in a masked fashion using the National Eye Institute grading system, which presents a score of 0 to 3 for each of the five areas of the cornea [19].

\subsection{Collection and Recovery of Traffic-Related $P M_{2.5}$}

Road dust was collected using a vacuum sweeper from a heavy traffic zone in Gangdong-Gu, Seoul, Korea, according to our previous procedures [20]. After baking the collected samples at $100{ }^{\circ} \mathrm{C}$ and sieving the particulate matter (PM) less than $75 \mu \mathrm{m}$, the samples were then suspended to collect $\mathrm{PM}_{2.5}$, which has a diameter of $2.5 \mu \mathrm{m}$ or less, using a Deakti Impactor (Dekati Ltd., Kangasala, Finland). This $\mathrm{PM}_{2.5}$ sample was mixed with phosphate-buffered saline (PBS) for $15 \mathrm{~min}$ under a sonication water bath. The total PM suspension was diluted with PBS to a concentration of $0.5 \mathrm{mg} / \mathrm{mL}[15,21]$. Lipopolysaccharide levels were quantitated using a LAL Chromogenic Endotoxin Assay (Thermo Scientific, Waltham, Massachusetts, USA) and were below $<0.1 \mathrm{EU} / \mathrm{mL}$, as the limits of detection. The mice were divided into two groups, a vehicle (PBS) control group, and the $\mathrm{PM}_{2.5}$ challenge group. 


\subsection{RNA Isolation and Real-Time Polymerase Chain Reaction}

We determined the cytokine expression profiles in the ocular surface. Isolation and purification of total RNA from the corneal and conjunctival tissue was done using Trizol (Invitrogen) and RNeasy Microkit (Qiagen). Complementary DNA (cDNA) was synthesized using SuperScript III ${ }^{\mathrm{TM}}$ reverse transcriptase (Invitrogen), and a quantitative real-time polymerase chain reaction was carried out using Taqman Universal PCR Mastermix and FAM-MGB dye-labeled primers (Applied Biosystems) for IL-1ß (Mm00434228_m1), IL-6 (Mm00446190_m1), TNF (Mm99999068_m1), mucin 5AC (MUC5AC) (Mm 01276705_g1), and glyceraldehydes 3-phosphate dehydrogenase (GAPDH) (Mm99999915_g1). One microliter of cDNA was put into each well in duplicate. The GAPDH gene was used as the endogenous reference for each reaction. Real-time PCR data were analyzed by the comparative threshold cycle method, and the relative expression level of each sample was presented as a fold change from normal control.

\subsection{CD11b-Positive Cellular Infiltration by Immunohistochemical Staining}

Fluorescein isothiocyanate (FITC)-conjugated rat anti-mouse CD11b (1:100; monocyte/macrophage marker; Biolegend, CA) and FITC-conjugated rat IgG2bk (isotype control; Biolegend) were used for the immunohistochemical assay. Three corneas from three mice per group were used and dissected corneas were fixed with acetone for $15 \mathrm{~min}$ at Day 14, as previously described [22,23]. After blocking nonspecific staining with an anti-FcR CD16/CD32 antibody (Biolegend), the specimens were immunostained with primary or isotype antibodies overnight, washed three times with PBS, incubated with secondary antibodies, and mounted with Vector Shield with DAPI (4,6 diamidino-2-phenylindole, Vector Laboratories). CD11 $\mathrm{b}^{+}$cells were counted at two areas in the center (within $2 \mu \mathrm{m}$ of the center) of each cornea in a masked fashion under an epifluorescence microscope (Nikon E800) at 40× magnification. The mean number of cells was analyzed by averaging the cell number in each area. The data are presented as averages \pm SEM of all mice observed.

\subsection{Periodic Acid Schiff (PAS) Staining for Conjunctival Goblet Cells}

Ipsilateral whole eyeballs, including the superior and inferior forniceal conjunctiva, were excised from $\mathrm{PM}_{2.5}$-treated or vehicle control mice following topical challenges for 14 days. Cryosections $(7 \mu \mathrm{m})$ at the center of the eye were air-dried for $30 \mathrm{~min}$ and subjected to periodic acid Schiff (PAS) staining. To count goblet cells, the average number of PAS-stained cells on the four different sections from each eye was calculated under a microscope (Eclipse E400, Nikon, Melville, NY, USA) using a ×20 objective by two observers in a blind study.

\subsection{Single-Cell Isolation from Draining Lymph Nodes and Conjunctivae For Flow Cytometric Analysis}

Single cells from conjunctivae and draining LNs were prepared with a $70 \mu \mathrm{m}$ cell strainer. Cellular viability was confirmed by Trypan blue exclusion assay. After incubating with Fc-blocking antibody in $0.5 \%$ BSA at $4{ }^{\circ} \mathrm{C}$ for $30 \mathrm{~min}$, and the cells were immunostained with FITC-conjugated anti-CD45, PE-Cy7-conjugated anti-CD11c, PE-Cy7-conjugated anti-c-kit, or PE-conjugated anti-I-A ${ }^{\mathrm{b}}$. Isotype control was used with the relevant antibodies (eBioscience). Stained cells were acquired on a BD ${ }^{\mathrm{TM}} \mathrm{LSR}$ II flow cytometer (Becton-Dickinson, Franklin Lakes, NJ, USA) and analyzed with Flowjo software (FlowJo, Ashland, OR, USA).

\subsection{In Vitro Stimulation of T Cells}

This procedure has been previously described [24]. Cervical draining LNs were harvested from neck dissection and $\mathrm{T}$ cells were isolated via magnetic-bead sorting using anti-CD90.2 antibodies (Miltenyi Biotec, Bergisch Gladbach, Germany). Enriched T cells were loaded into 96 well plates at a concentration of $1.5 \times 10^{6} / \mathrm{mL}$. Bone-marrow-related dendritic cells (BMDCs) prepared as previously described were co-cultured with T cells $\left(0.75 \times 10^{6} / \mathrm{mL}\right)$ and $10 \%$ FBS for $48 \mathrm{~h}$. The supernatants were 
harvested after stimulation with PMA/ionomycin (Sigma-Aldrich Corp., St. Louis, MO, USA) for $6 \mathrm{~h}$. Cytokines such as IFN- $\gamma$, IL-4, and IL-13 were measured via ELISA, as per manufacturer's instructions (Ready-set-go ELISA kit; eBioscience, Waltham, MA, USA).

\subsection{Quantitation of IgE in Serum}

Following 14 days of topical $\mathrm{PM}_{2.5}$ challenge, blood was collected by cardiac puncture after euthanasia. Sera were isolated using coagulation and centrifugation, and then analyzed using an ELISA kit for total mouse IgE (88-50460, eBioscience, Waltham, MA, USA).

\subsection{TdT-Mediated dUTP Nick End Labeling (TUNEL) Assay}

We evaluated surface epithelial damage using a TdT-mediated dUTP nick end labeling (TUNEL) assay. To evaluate corneal epithelial cell damages, $7 \mu \mathrm{m}$ cryostat cross-sections were fixed in $4 \%$ paraformaldehyde at Day 14, and TUNEL staining was then performed according to the manufacturer's protocol (TUNEL Kit, Roche, Basel, Switzerland). Images were obtained under an epifluorescence microscope with 100× magnification. Both TUNEL-positive and DAPI-positive cells were calculated at the central cornea (100 $\mu \mathrm{m}$ width $\times 40 \mu \mathrm{m}$ depth areas of epithelial layer) in a masked fashion, as previously described [25].

\subsection{Statistical Analysis}

Data are expressed as mean \pm standard error of the mean (SEM) of three independently repeated experiments. Statistical significance among the groups was analyzed via a one-way ANOVA followed by Tukey's post hoc tests using Prism software (version 5.0; GraphPad, San Diego, CA, USA). $p<0.05$ was considered statistically significant.

\section{Results}

\subsection{Clinical Signs of Ocular Surface Injury}

$\mathrm{PM}_{2.5}$ was applied to the mice for 14 days. At Days 5 and 14, PM-exposed groups showed a significant increase in corneal fluorescein staining compared to the vehicle control groups $(p<0.001$, Figure 1).

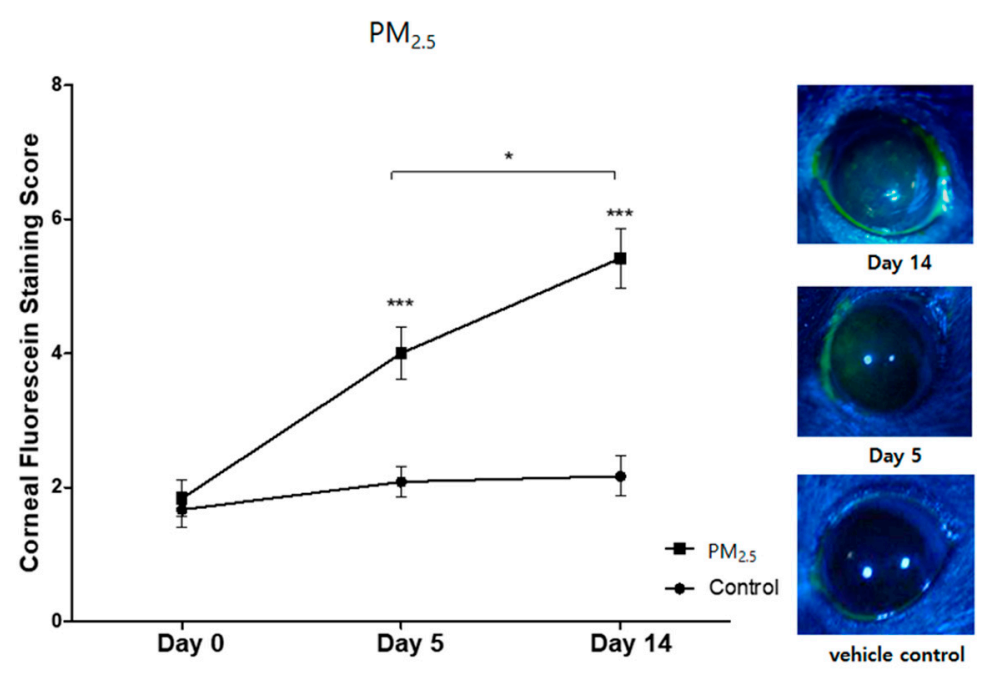

Figure 1. Traffic-related $\mathrm{PM}_{2.5}$ challenges led to a significant increase in the corneal fluorescein staining score compared to the vehicle control at Day 5 and Day 14. ${ }^{*} p<0.05,{ }^{* * *}$ indicates $p<0.0001$. Data are presented as the mean \pm standard error of the mean (SEM) of three experiments. Each experiment consisted of eight mice per group. 


\subsection{Inflammatory Cells' Infiltration to Cornea and Conjunctiva}

The mean number of corneal CD11b+ cells was $85.3 \pm 4.6$ cells $/ \mathrm{mm}^{2}$ in the vehicle control group, and $112.7 \pm 5.7$ cells $/ \mathrm{mm}^{2}$ and $133.6 \pm 4.8$ cells $/ \mathrm{mm}^{2}$ in the $\mathrm{PM}_{2.5}$ challenge group at Day 5 and Day 14, respectively $(p<0.05$, Figure $2 \mathrm{~A}, \mathrm{~B})$. Conjunctivae were also harvested for flow cytometric enumeration of mast cells ( $\mathrm{CD} 45+\mathrm{c}-\mathrm{Kit}+$ ). This population was augmented in $\mathrm{PM}_{2.5}$-exposed mice relative to the control group $(p<0.05$, Figure $2 \mathrm{C}, \mathrm{D})$. These findings suggest that $\mathrm{PM}_{2.5}$ induced an allergic ocular response, as the mast cell is a key immune factor in the Th2-mediated responses. After the $\mathrm{PM}_{2.5}$ challenge, the degree of inflammatory cell infiltration at the ocular surface increased significantly compared to the vehicle control.

(B)

(A)

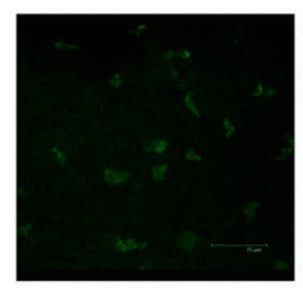

5 days

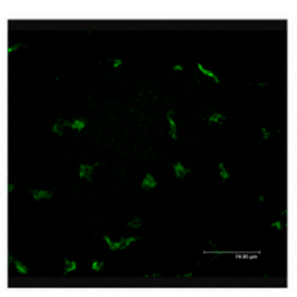

14 days

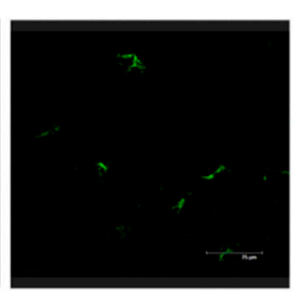

Control

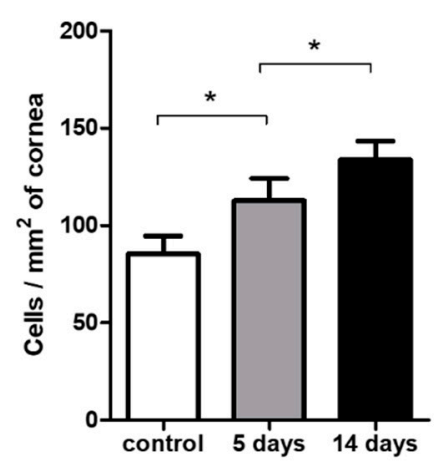

(C)

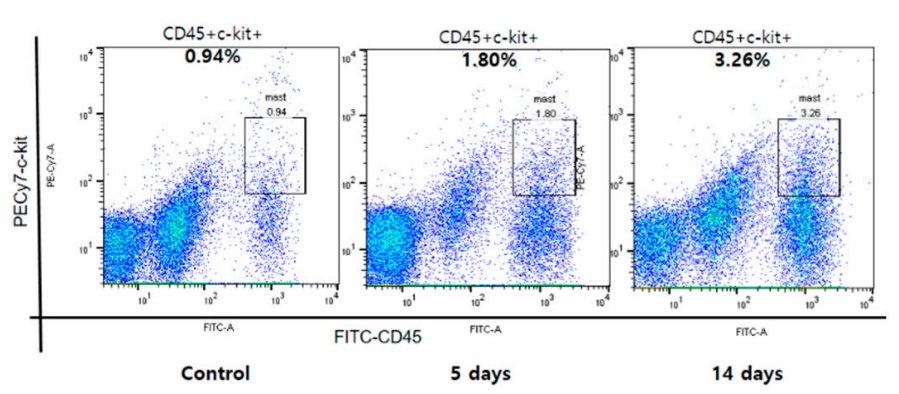

(D)

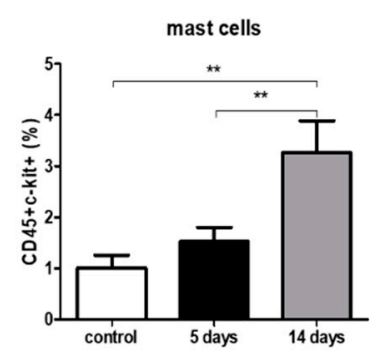

Figure 2. Inflammatory cells' accumulation in the ocular surface in a murine model of traffic-related $\mathrm{PM}_{2.5}$ exposure. (A) Representative epifluorescence images showing CD11b+ cells (green) in the central corneas (scale bar: $75 \mu \mathrm{m}$ ). (B) Traffic-related $\mathrm{PM}_{2.5}$ increased the number of CD11b+ cells in the central corneas, compared to the vehicle-treated groups. (C) Conjunctivae were harvested from these mice and the flow cytometry of mast cells (CD45+c-kit+) was analyzed. Figures represent three independent experiments. (D) Data are representative of three independent experiments. $p$-value signs indicate: ${ }^{*} p<0.05,{ }^{* *} p<0.001$. Data are presented as the mean \pm SEM of three experiments. Each experiment consisted of three to four corneas per group.

\subsection{Inflammatory Cytokine Expression in the Ocular Surface}

A real-time polymerase chain reaction was used to quantify the transcripts encoding IL-1 $\beta$, IL-6, and TNF in the corneas and conjunctivae of the two groups (Figure 3). The $\mathrm{PM}_{2.5}$ challenge significantly increased relative expression of IL- $1 \beta$ ( $p<0.05$ vs. vehicle), IL-6 ( $p<0.05$ vs. vehicle), and TNF- $\alpha$ $(p<0.05$ vs. vehicle) transcripts at the corneas, and MUC5AC transcripts at the conjunctivae $(p<0.05$ vs. vehicle). To explore the immunogenic function of antigen-presenting cells (APCs) in this model, we evaluated the frequencies of mature APCs (MHC-II ${ }^{\text {high }} \mathrm{CD} 11 \mathrm{c}^{+}$cells) in the draining lymph nodes. 
$\mathrm{PM}_{2.5}$ exposure led to the maturation of APCs in draining LNs as compared to the vehicle controls $(p<0.05$, Figure $4 \mathrm{~A}, \mathrm{~B})$.

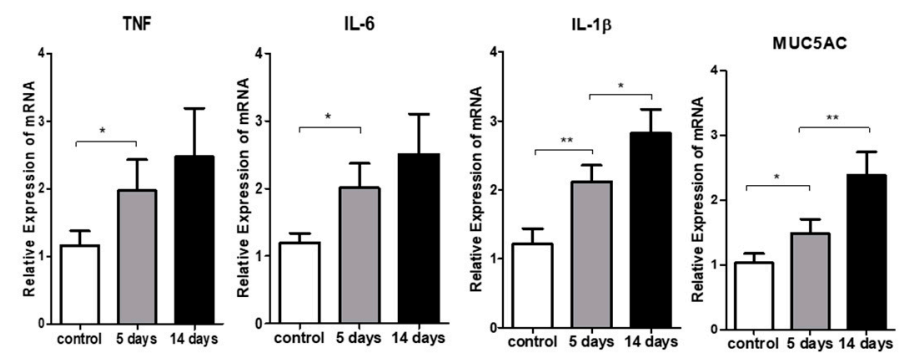

Figure 3. Cytokine expression in the ocular surface. Real-time polymerase chain reaction analysis showed that $\mathrm{PM}_{2.5}$ exposure significantly increased the relative expressions of TNF (* $p<0.05$ ), IL-6 $\left({ }^{*} p<0.05\right)$, and IL-1ß ${ }^{*} p<0.05$ and $\left.{ }^{* *} p<0.01\right)$ in the corneas, and mucin 5AC (MUC5AC) $\left({ }^{*} p<0.05\right.$ and $\left.{ }^{* *} p<0.01\right)$ in the conjunctivae, compared to the vehicle control groups. Data were normalized to GAPDH mRNA as an internal control, and values were then expressed as the fold change over the normal naive corneas. Data are presented as the mean $\pm \mathrm{SEM}$ of three experiments. Each experiment consisted of three corneas or conjunctivae per group.

(A)

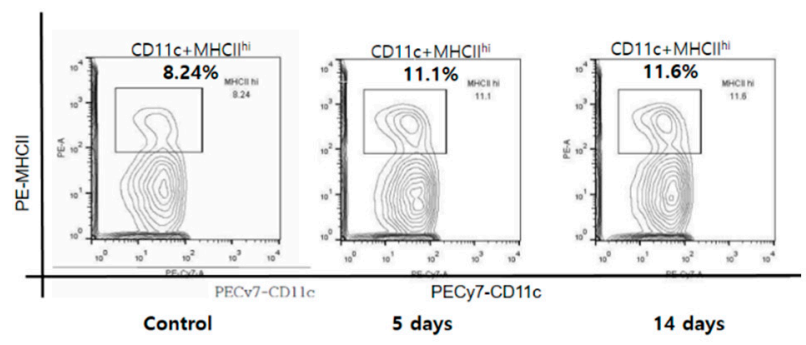

(B)

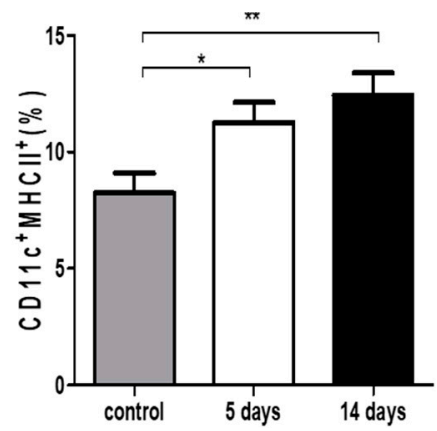

Figure 4. Ocular inflammation via exposure to traffic-related PM was associated with increased levels of mature dendritic cells (MHC-II ${ }^{\text {high }} \mathrm{CD} 11 \mathrm{c}^{+}$cells) in the draining cervical lymph nodes (LN). (A) Representative flow data demonstrated that $\mathrm{PM}_{2.5}$ challenge increased the frequency of mature APCs (MHC-II ${ }^{\text {high }} \mathrm{CD} 11 \mathrm{c}^{+}$) in the draining $\mathrm{LN}$ compared with the vehicle control. (B) Data are presented as the mean \pm SEM of three independent experiments. Each experiment consisted of two mice per group. $p$-value signs indicate ${ }^{*} p<0.05$; ${ }^{* *} p<0.001$.

\subsection{Effect of $P M_{2.5}$ on Apoptosis of the Corneal Epithelial Cells}

The TUNEL assay indicated that apoptosis was induced in the superficial and basal epithelium of $\mathrm{PM}_{2.5}$-exposed corneas, whereas a few apoptotic cells were observed in the corneal epithelium of the vehicle group. The number of apoptotic cells was significantly increased in the $\mathrm{PM}_{2.5}$-exposed corneas at Days 5 and 14 compared with the vehicle controls $(p<0.005$, Figure $5 \mathrm{~A}, \mathrm{~B})$. 
(A)

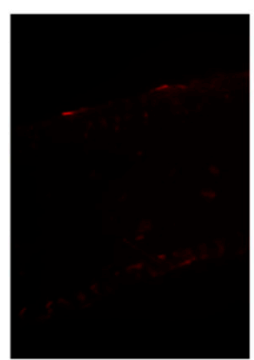

control

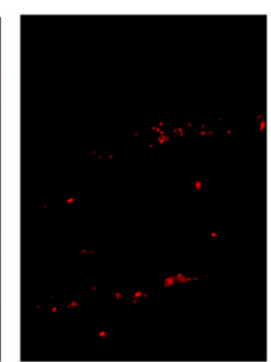

day 5

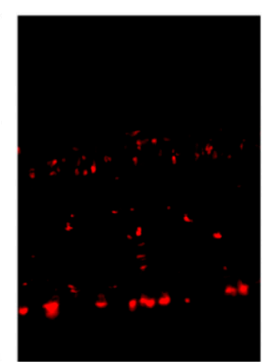

day 14
(B)

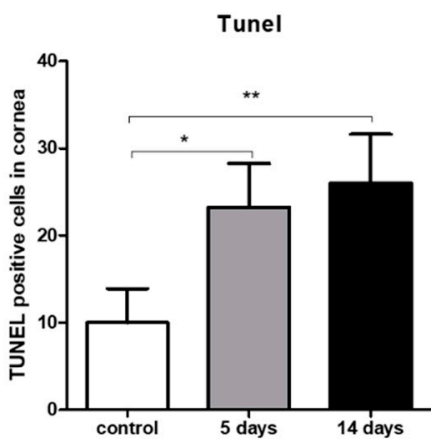

Figure 5. Quantitation of TUNEL-positive cells in the corneal epithelial layer. (A) Representative photograph of TUNEL staining of the cornea in both groups. (B) The number of apoptotic cells (red) in $\mathrm{PM}_{2.5}$-exposed corneas was significantly increased as compared to the vehicle control. $p$-value signs indicate ${ }^{*} p<0.05 ;{ }^{* *} p<0.001$. Data are presented as the mean $\pm \mathrm{SEM}$ of three experiments. Each experiment consisted of three to four corneas per group.

\section{5. $P M_{2.5}$ Did Not Decrease the Number of Goblet Cells in the Conjunctiva}

PAS staining of the conjunctiva showed the number of goblet cells, which are responsible for mucous tear production. We measured the number of mucin-filled goblet cells in PAS-stained conjunctival sections. There was no statistically significant difference in the conjunctival goblet cells between the $\mathrm{PM}_{2.5}$ exposure group and the vehicle control group ( $p=0.152$, Figure $\left.6 \mathrm{~A}, \mathrm{~B}\right)$.

(A)

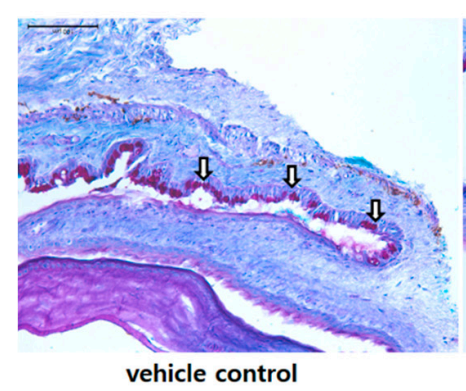

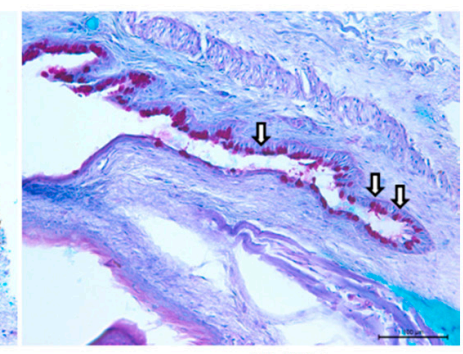

PM2.5
(B)

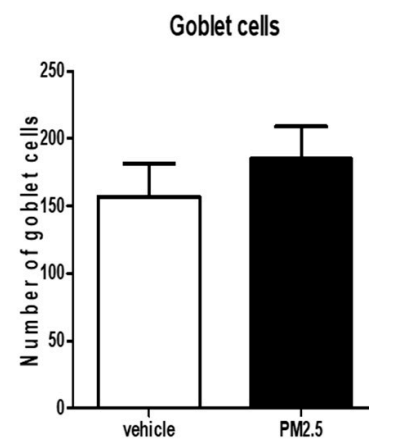

Figure 6. Conjunctival goblet cell density after $\mathrm{PM}_{2.5}$ exposure. (A) Representative photograph of periodic acid Schiff (PAS) staining of the conjunctiva at Day 14. (B) The goblet cell counts (white arrow) in the conjunctiva were not different between $\mathrm{PM}_{2.5}$ and vehicle control mice. The data are presented as the mean \pm SEM. Each experiment consisted of four eyes per group. The scale bar indicates $100 \mu \mathrm{m}$.

\section{6. $P M_{2.5}$ Induced Type 2 CD4 T-Cell Immune Responses in the Draining LNs}

Purified T cells were stimulated with BMDC in vitro to determine whether $\mathrm{PM}_{2.5}$ led to the immunological modulation of draining LNs. Cytokine secretions into the supernatants were quantified via ELISA. The levels of Th2 cytokines such as IL-4 ( $p<0.001$ versus vehicle) and IL-13 $(p<0.001$ versus vehicle), but not the Th1 cytokine IFN- $\gamma$, were significantly increased compared with those in the vehicle-treated mice ( $p=0.217$ versus vehicle; Figure 7A). PM-exposed groups also displayed significantly higher levels of serum IgE compared to the vehicle controls $(p<0.05$ versus vehicle; Figure 7B). 
(A)

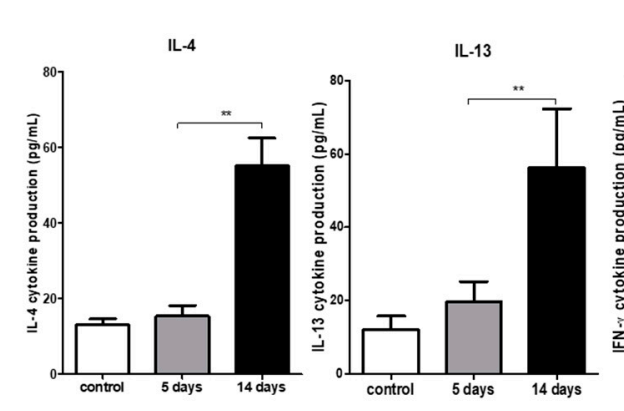

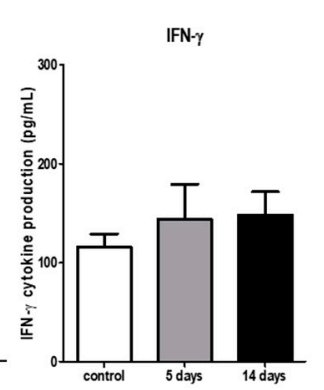

(B)

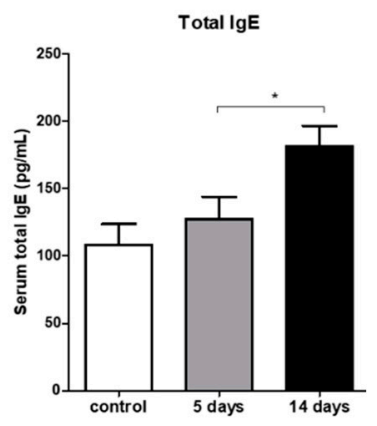

Figure 7. Traffic-related $\mathrm{PM}_{2.5}$ enhances Th2-mediated allergic responses in the eyes. (A) Draining cervical lymph nodes were harvested after the euthanasia of mice on Day 14 ( $\mathrm{n}=$ four mice per group). Purified $\mathrm{T}$ cells with a magnetic bead sorting were stimulated with OVA-pulsed bone marrow dendritic cells for $48 \mathrm{~h}$ and then re-stimulated with phorbol myristate acetate/ionomycin for up to $4 \mathrm{~h}$. Cytokines in culture supernatants were quantified by ELISA. (B) Exposure to $\mathrm{PM}_{2.5}$ contributed to increased total IgE in the serum. Blood was collected from mice after 14 days of topical challenge with $\mathrm{PM}_{2.5}$ or the vehicle. Sera were isolated and measured for total IgE. Data are presented from three to four independent experiments as the mean \pm SEM. ${ }^{*} p<0.05 .{ }^{* *} p<0.01$.

\section{Discussion}

This study evaluated whether exposure to traffic-related $\mathrm{PM}_{2.5}$ modulates inflammatory responses on the ocular surface and in draining LNs in healthy mice. This PM was collected from the road dust of a downtown area near main streets in Gangdong-Gu, Seoul, Korea. Our study demonstrated that exposures to $\mathrm{PM}_{2.5}$ enhanced ocular surface impairment and allergic responses, as supported by increased apoptosis of the ocular surface, elevated levels of total IgE in the serum, and enriched secretions of Th2 cytokines in draining LNs. In addition, $\mathrm{PM}_{2.5}$ led to an increase in mast cell infiltration into the conjunctiva and maturation of DC to mediate the Th2 response. Our evidence suggests that traffic-related $\mathrm{PM}_{2.5}$ modifies and enhances the ocular allergic immune response in the mouse model, rather than dry eye disease (DED).

The ocular surface is exposed to the external environment and air pollution. Environmental pollution can cause ocular symptoms. Various investigations have demonstrated that exposure to higher levels of traffic-related air pollution increases ocular irritation and tear film instability, close to DED [4,9-11,17]. A high concentration of air pollution in metropolitan areas increases the likelihood of being diagnosed with dry eye disease three to four times, compared with relatively low concentrations of pollutants [14]. Gupta et al. demonstrated that air pollution was associated with a high prevalence of DED symptoms, such as irritation, the sensation of a foreign body, redness, tear film instability, and photophobia [26]. DED was recently defined as "a multifactorial disease of the ocular surface characterized by a loss of homeostasis of the tear film and accompanied by ocular symptoms" by the Tear Film \& Ocular Surface Society (TFOS) Dry Eye Workshop II (DEW II) report [27]. DED presents as ocular surface discomfort, changes in visual acuity, and ocular surface damage and inflammation, including loss of goblet cells in the conjunctiva, aqueous tear deficiency, infiltration of immune cells into the cornea, and elevated levels of inflammatory cytokines in tears [28]. Torricelli et al. suggested a correlation between ambient levels of air pollution and tear osmolality, which is the core mechanism of ocular surface damage and inflammation in dry eye patients $[9,17]$. In this study, traffic-related $\mathrm{PM}_{2.5}$ increased corneal fluorescein staining and epithelial apoptosis, similarly to the clinical signs of DED. Our previous study on human corneal epithelial cells showed that traffic-related $\mathrm{PM}_{2.5}$ decreased cell viability and disrupted cellular membrane integrity [20].

According to the experimental DED studies, the stimulation and expansion of CD4+ T cells occur in the secondary lymphoid tissues in DED [29-31]. IFN- $\gamma$-secreting CD4+ T (Th1) and IL-17-secreting CD4+ T (Th17) cells are generated in the draining LNs of murine DED [29-31]. IFN- $\gamma$ secreted 
from Th1 cells contributes to the corneal barrier disruption and decreased goblet cell density in the conjunctivae [32-34]. However, in our study, $\mathrm{PM}_{2.5}$ increased levels of Th2 cytokines such as IL-4 and IL-13 in the draining cervical LNs, but not of the Th1 cytokine IFN- $\gamma$. Moreover, total serum IgE was significantly increased by $\mathrm{PM}_{2.5}$ exposures, like in allergic diseases. Allergic conjunctivitis, one of the most common ocular diseases, presents as an allergic inflammatory reaction to many substances. It is accompanied by discomfort, itching, conjunctival redness, swelling, and discharge. In this study, exposure to $\mathrm{PM}_{2.5}$ also presented as mild conjunctival redness and mucous discharge, but not significantly, compared to the vehicle control. Allergic conjunctivitis shares a common pathogenesis with other allergic diseases. Therefore, allergenic CD4+ T helper (Th)-2 cells and their cytokines (IL-4, IL-5, IL-13) mediate allergic responses, as supported by IgE production, mast cell and eosinophil accumulation, and mucus production [35].

Recently, some reports have indicated that air pollution causes allergic diseases. In a previous study in European cities, $15 \%$ of all childhood asthma exacerbations were attributed to exposure to road transport pollutants [36], and both urbanization and outdoor air pollution are important contributors to asthma $[37,38]$. Mimura et al. found a significant association between the number of outpatient visits for allergic conjunctivitis and the $\mathrm{PM}_{2.5}$ level, especially during the non-pollen season. Our findings were consistent with those of previous studies on the respiratory system [39]. Exposure to $\mathrm{PM}_{2.5}$ is associated with asthma and allergic respiratory symptoms [39,40], but little is known about the influence of $\mathrm{PM}_{2.5}$ on ocular allergies. Several experimental studies demonstrated that combined exposure to diesel exhaust particles and an antigen from a house dust mite induced a mixed Th2 and Th17 response in a murine model, and exposure to PM results in oxidative injury to the airways, inflammation, remodeling, and increased risk of aeroallergen sensitization [39-41]. In this study, traffic-related $\mathrm{PM}_{2.5}$ increased the maturation of APCs at cervical draining LNs, which might be mediated by increased inflammatory cytokines, including IL- $1 \beta$, IL- 6 , and TNF- $\alpha$, at the ocular surface. Inflammatory signals such as TNF, IL-1 $\beta$, and heat shock proteins increase DC maturation (increased expression of CD80 and MHCII), initiating a T-cell-mediated immune response, as reported previously [42,43]. These studies have shown that a PM-mediated enhanced activation of antigen-presenting cells (APCs) such as DC could augment the adaptive immune system, including proliferation of Th2 cells, Th2 cytokine secretion, mast cell and eosinophil recruitment, and severe allergic inflammation [43,44]. Our data also showed increased maturation of APCs at cervical LNs. We postulate that maturation of APCs mediated by $\mathrm{PM}_{2.5}$ enhances the Th2 response in draining LNs. $\mathrm{PM}_{2.5}$ could drive a pro-allergic Th2-dominant immune response, orchestrated by DC [43-45]. Although the mechanisms by which traffic-related $\mathrm{PM}_{2.5}$ modulates ocular allergic inflammation remain unclear, we suggest they include PM-mediated ocular surface inflammation, APC maturation, aeroallergen sensitization, and Th2-derived immunological responses [43-46].

One of the hallmarks of DED is a decrease in the number of goblet cells [33,47]. However, our results indicate that hyperplasia or proliferation of goblet cells in the conjunctiva was not significantly changed by $\mathrm{PM}_{2.5}$, but mRNA expression of MUC5AC was increased after $\mathrm{PM}_{2.5}$ exposure. Previous investigations have reported that higher levels of traffic-related air pollution increased the frequency of ocular irritation with goblet cells hyperplasia in tarsal conjunctiva [9]. The goblet cell hyperplasia and increased mucin production represent an ocular mucosa response to chronic inflammatory or toxic stimuli [48,49]. Kondo et al. demonstrated that human recombinant IL-13, but not IL-4, can differentiate mature goblet cells that produce MUC5AC proteins in in vitro guinea pig tracheal epithelial cells [50]. Increased levels of IL-13, according to the Th2 response after traffic-related $\mathrm{PM}_{2.5}$ exposure, might stimulate goblet cell differentiation and MUC5AC production at the conjunctivae, which is a common pathogenesis in allergic diseases. Moreover, goblet cell hyperplasia with mucin production seems to protect the ocular surface from environmental toxins [17]. Research has demonstrated the major signs and symptoms of air pollution are similar to those of DED, including ocular fluorescein staining, epithelial apoptosis, elevated tear osmolality, loss of goblet cells, and ocular irritation, which may occur as a result of chronic exposure to air pollution [14,17]. 
One major limitation of this study is that the environmental exposure to $\mathrm{PM}_{2.5}$ might be different from the topical administration of $\mathrm{PM}_{2.5}$. We need to modify the concentration and the mode of exposure in future studies. In addition, a human ocular surface might be different from an animal model. Therefore, a large-scale, long-term clinical study is needed to evaluate the actual effects of fine ambient PM exposure on the ocular surface.

\section{Conclusions}

Traffic-related $\mathrm{PM}_{2.5}$ exposure presented Th2-dominant allergic immune response in the draining LNs, rather than the Th1 response of the DED model. $\mathrm{PM}_{2.5}$ increased epithelial disruption and inflammation on the ocular surface, a main sign of DED, which might increase the penetration of aeroallergens into the ocular tissues and maturation of APCs to develop ocular allergy. This research may help diagnose and treat air-pollution-associated ocular disease.

Author Contributions: Conceptualization, H.S.L., S.H., J.-W.S., and K.-J.J.; formal analysis, H.S.L. and S.H.; investigation, H.S.L., S.H., J.-W.S., and K.-J.J.; writing—original draft preparation, H.S.L. and S.H.; writing-review and editing, H.S.L., S.H., J.-W.S., and K.-J.J. All authors have read and agreed to the published version of the manuscript.

Funding: This work was funded by the Korea Ministry of Environment as Environmental Health Action Program (2016001360005), the Ministry of Health and Welfare as Korea Health Technology R\&D Project (HI17C2012030018), and the Ministry of Education as Basic Science Research Program (2016R1C1B1010535).

Conflicts of Interest: The authors have no commercial or proprietary interests in the products or companies mentioned in this article and declare no financial interest.

\section{References}

1. Burnett, R.; Chen, H.; Szyszkowicz, M.; Fann, N.; Hubbell, B.; Pope, C.A.; Apte, J.S.; Brauer, M.; Cohen, A.; Weichenthal, S.; et al. Global estimates of mortality associated with long-term exposure to outdoor fine particulate matter. Proc. Natl. Acad. Sci. USA 2018, 115, 9592-9597. [CrossRef] [PubMed]

2. Achilleos, S.; Kioumourtzoglou, M.-A.; Wu, C.-D.; Schwartz, J.D.; Koutrakis, P.; Papatheodorou, S.I. Acute effects of fine particulate matter constituents on mortality: A systematic review and meta-regression analysis. Environ. Int. 2017, 109, 89-100. [CrossRef] [PubMed]

3. Boogaard, H.; Walker, K.; Cohen, A.J. Air pollution: The emergence of a major global health risk factor. Int. Health 2019, 11, 417-421. [CrossRef] [PubMed]

4. Tan, G.; Li, J.; Yang, Q.; Wu, A.; Qu, D.-Y.; Wang, Y.; Ye, L.; Bao, J.; Shao, Y. Air pollutant particulate matter 2.5 induces dry eye syndrome in mice. Sci. Rep. 2018, 8, 17828. [CrossRef] [PubMed]

5. Srimuruganandam, B.; Nagendra, S.M.S. Source characterization of PM10 and PM2.5 mass using a chemical mass balance model at urban roadside. Sci. Total. Environ. 2012, 433, 8-19. [CrossRef]

6. Huang, K.L.; Liu, S.Y.; Chou, C.C.; Lee, Y.H.; Cheng, T.J. The effect of size-segregated ambient particulate matter on Th1/Th2-like immune responses in mice. PLoS ONE 2017, 12, e0173158. [CrossRef]

7. Schwartz, J.; Neas, L.M. Fine particles are more strongly associated than coarse particles with acute respiratory health effects in schoolchildren. Epidemiology 2000, 11, 6-10. [CrossRef]

8. Wang, J.; Fonn, D.; Simpson, T.L.; Jones, L.W. Precorneal and pre- and postlens tear film thickness measured indirectly with optical coherence tomography. Investig. Opthalmol. Vis. Sci. 2003, 44, 2524-2528. [CrossRef]

9. Novaes, P.; Saldiva, P.H.; Matsuda, M.; Macchione, M.; Rangel, M.P.; Kara-José, N.; Berra, A. The effects of chronic exposure to traffic derived air pollution on the ocular surface. Environ. Res. 2010, 110, 372-374. [CrossRef]

10. Malerbi, F.K.; Martins, L.C.; Saldiva, P.H.; Braga, A. Ambient levels of air pollution induce clinical worsening of blepharitis. Environ. Res. 2012, 112, 199-203. [CrossRef]

11. Galor, A.; Kumar, N.; Feuer, W.; Lee, D.J. Environmental factors affect the risk of dry eye syndrome in a United States veteran population. Ophthalmolgy 2014, 121, 972-973.e1. [CrossRef] [PubMed]

12. Versura, P.; Profazio, V.; Cellini, M.; Torreggiani, A.; Caramazza, R. Eye discomfort and air pollution. Ophthalmolgy 1999, 213, 103-109. [CrossRef] [PubMed] 
13. Vitar, R.M.L.; Tau, J.; Reides, C.G.; Berra, A.; Ferreira, S.; Llesuy, S. Evaluation of oxidative stress markers in human conjunctival epithelial cells exposed to Diesel Exhaust Particles (DEP). Investig. Opthalmol. Vis. Sci. 2015, 56, 7058. [CrossRef] [PubMed]

14. Tau, J.; Novaes, P.; Matsuda, M.; Tasat, D.; Saldiva, P.H.; Berra, A. Diesel exhaust particles selectively induce both proinflammatory cytokines and mucin production in cornea and conjunctiva human cell lines. Investig. Opthalmol. Vis. Sci. 2013, 54, 4759-4766. [CrossRef]

15. Eom, Y.; Song, J.S.; Lee, H.K.; Kang, B.; Kim, H.C.; Lee, H.K.; Kim, H.M. The effect of ambient titanium dioxide microparticle exposure to the ocular surface on the expression of inflammatory cytokines in the eye and cervical lymph nodes. Investig. Opthalmol. Vis. Sci. 2016, 57, 6580-6590. [CrossRef]

16. Federico, K.; Claudio, A.B.; Carlos, C.D.; Annette, P.U.; Sophie, B.; Heather, A.R.; Markus, A. Contributions to cities' ambient particulate matter (PM): A systematic review of local source contributions at global level. Atmos. Environ. 2015, 120, 475-483.

17. Torricelli, A.; Novaes, P.; Matsuda, M.; Braga, A.; Saldiva, P.H.; Alves, M.R.; Monteiro, M.L.R. Correlation between signs and symptoms of ocular surface dysfunction and tear osmolarity with ambient levels of air pollution in a large metropolitan area. Cornea 2013, 32, e11-e15. [CrossRef]

18. Wolkoff, P. Ocular discomfort by environmental and personal risk factors altering the precorneal tear film. Toxicol. Lett. 2010, 199, 203-212. [CrossRef]

19. Lemp, A. Report of the national eye institute/industry workshop on clinical trials in dry eyes. CLAO J. 1995, 21, 221-232.

20. Yoon, S.; Han, S.; Jeon, K.-J.; Kwon, S. Effects of collected road dusts on cell viability, inflammatory response, and oxidative stress in cultured human corneal epithelial cells. Toxicol. Lett. 2017, 284, 152-160. [CrossRef]

21. Han, J.Y.; Kang, B.; Eom, Y.; Kim, H.M.; Song, J.S. Comparing the effects of particulate matter on the ocular surfaces of normal eyes and a dry eye rat model. Cornea 2017, 36, 605-610. [CrossRef] [PubMed]

22. Goyal, S.; Chauhan, S.K.; Zhang, Q.; Dana, R. Amelioration of murine dry eye disease by topical antagonist to chemokine receptor 2. Arch. Ophthalmol. 2009, 127, 882. [CrossRef] [PubMed]

23. Lee, H.S.; Hattori, T.; Park, E.Y.; Stevenson, W.; Chauhan, S.K.; Dana, R. Expression of toll-like receptor 4 contributes to corneal inflammation in experimental dry eye disease. Investig. Opthalmol. Vis. Sci. 2012, 53, 5632-5640. [CrossRef] [PubMed]

24. Schlereth, S.; Lee, H.S.; Khandelwal, P.; Saban, D.R. Blocking CCR7 at the ocular surface impairs the pathogenic contribution of dendritic cells in allergic conjunctivitis. Am. J. Pathol. 2012, 180, 2351-2360. [CrossRef]

25. Lee, H.S.; Chauhan, S.K.; Okanobo, A.; Nallasamy, N.; Dana, R. Therapeutic efficacy of topical epigallocatechin gallate in murine dry eye. Cornea 2011, 30, 1465-1472. [CrossRef]

26. Gupta, S.K.; Gupta, S.C.; Agarwal, R.; Sushma, S.; Agrawal, S.S.; Saxena, R. A multicentric case-control study on the impact of air pollution on eyes in a metropolitan city of India. Indian J. Occup. Environ. Med. 2007, 11, 37-40. [CrossRef]

27. Craig, J.P.; Nichols, K.K.; Akpek, E.K.; Caffery, B.; Dua, H.S.; Joo, C.-K.; Liu, Z.; Nelson, J.; Nichols, J.J.; Tsubota, K.; et al. TFOS DEWS II definition and classification report. Ocul. Surf. 2017, 15, 276-283. [CrossRef]

28. Yamaguchi, T. Inflammatory response in dry eye. Investig. Opthalmol. Vis. Sci. 2018, 59, DES192-DES199. [CrossRef]

29. Pflugfelder, S.C.; Corrales, R.M.; De Paiva, C.S. T helper cytokines in dry eye disease. Exp. Eye Res. 2013, 117, 118-125. [CrossRef]

30. Chauhan, S.K.; El Annan, J.; Ecoiffier, T.; Goyal, S.; Zhang, Q.; Saban, D.R.; Dana, R. Autoimmunity in dry eye is due to resistance of Th17 to Treg suppression1. J. Immunol. 2009, 182, 1247-1252. [CrossRef]

31. El Annan, J.; Chauhan, S.K.; Ecoiffier, T.; Zhang, Q.; Saban, D.R.; Dana, R. Characterization of effector T cells in dry eye disease. Investig. Opthalmol. Vis. Sci. 2009, 50, 3802-3807. [CrossRef] [PubMed]

32. Barabino, S.; Chen, Y.; Chauhan, S.; Dana, R. Ocular surface immunity: Homeostatic mechanisms and their disruption in dry eye disease. Prog. Retin. Eye Res. 2012, 31, 271-285. [CrossRef] [PubMed]

33. De Paiva, C.S.; Villarreal, A.L.; Corrales, R.M.; Rahman, H.T.; Chang, V.Y.; Farley, W.J.; Stern, M.E.; Niederkorn, J.Y.; Li, D.-Q.; Pflugfelder, S.C. Dry Eye-induced conjunctival epithelial squamous metaplasia is modulated by interferon- $\gamma$. Investig. Opthalmol. Vis. Sci. 2007, 48, 2553-2560. [CrossRef] [PubMed] 
34. De Paiva, C.S.; Chotikavanich, S.; Pangelinan, S.B.; Pitcher, J.D.; Fang, B.; Zheng, X.; Ma, P.; Farley, W.J.; Siemasko, K.F.; Niederkorn, J.Y.; et al. IL-17 disrupts corneal barrier following desiccating stress. Mucosal Immunol. 2009, 2, 243-253. [CrossRef]

35. Irkeç, M.; Bozkurt, B. Molecular immunology of allergic conjunctivitis. Curr. Opin. Allergy Clin. Immunol. 2012, 12, 534-539. [CrossRef]

36. Perez, L.; Declercq, C.; Iñiguez, C.; Aguilera, I.; Badaloni, C.; Ballester, F.; Bouland, C.; Chanel, O.; Cirarda, F.B.; Forastiere, F.; et al. Chronic burden of near-roadway traffic pollution in 10 European cities (APHEKOM network). Eur. Respir. J. 2013, 42, 594-605. [CrossRef]

37. Wong, G.W.; Chow, C.M. Childhood asthma epidemiology: Insights from comparative studies of rural and urban populations. Pediatr. Pulmonol. 2007, 43, 107-116. [CrossRef]

38. Robinson, C.L.; Baumann, L.M.; Romero, K.; Combe, J.M.; Gómez, A.; Gilman, R.H.; Cabrera, L.; Gonzalvez, G.; Hansel, N.N.; Wise, R.A.; et al. Effect of urbanisation on asthma, allergy and airways inflammation in a developing country setting. Thorax 2011, 66, 1051-1057. [CrossRef]

39. Mimura, T.; Ichinose, T.; Yamagami, S.; Fujishima, H.; Kamei, Y.; Goto, M.; Takada, S.; Matsubara, M. Airborne particulate matter (PM2.5) and the prevalence of allergic conjunctivitis in Japan. Sci. Total Environ. 2014, 487, 493-499. [CrossRef]

40. Guarnieri, M.; Balmes, J.R. Outdoor air pollution and asthma. Lancet 2014, 383, 1581-1592. [CrossRef]

41. Brandt, E.; Kovacic, M.B.; Lee, G.-B.; Gibson, A.M.; Acciani, T.H.; Le Cras, T.D.; Ryan, P.H.; Budelsky, A.L.; Hershey, G.K.K. Diesel exhaust particle induction of IL-17A contributes to severe asthma. J. Allergy Clin. Immunol. 2013, 132, 1194-1204.e2. [CrossRef] [PubMed]

42. Fujii, S.; Liu, K.; Smith, C.; Bonito, A.J.; Steinman, R.M. The linkage of innate to adaptive immunity via maturing dendritic cells in vivo requires CD40 ligation in addition to antigen presentation and CD80/86 costimulation. J. Exp. Med. 2004, 21, 1607-1618. [CrossRef] [PubMed]

43. Castañeda, A.R.; Bein, K.J.; Smiley-Jewell, S.; Pinkerton, K.E. Fine particulate matter (PM2.5) enhances allergic sensitization in BALB/cmice. J. Toxicol. Environ. Health Part A 2017, 80, 197-207. [CrossRef] [PubMed]

44. Li, N.; Wang, M.; Barajas, B.; Sioutas, C.; Williams, M.A.; Nel, A.E. Nrf2 deficiency in dendritic cells enhances the adjuvant effect of ambient ultrafine particles on allergic sensitization. J. Innate Immun. 2013, 5, 543-554. [CrossRef] [PubMed]

45. Williams, M.A.; Rangasamy, T.; Bauer, S.M.; Killedar, S.; Karp, M.; Kensler, T.W.; Yamamoto, M.; Breysse, P.; Biswal, S.; Georas, S.N. Disruption of the transcription factor Nrf2 promotes pro-oxidative dendritic cells that stimulate Th2-like immunoresponsiveness upon activation by ambient particulate matter. J. Immunol. 2008, 181, 4545-4559. [CrossRef] [PubMed]

46. Weng, C.-M.; Wang, C.-H.; Lee, M.-J.; He, J.-R.; Huang, H.-Y.; Chao, M.-W.; Chung, K.F.; Kuo, H.-P. Aryl hydrocarbon receptor activation by diesel exhaust particles mediates epithelium-derived cytokines expression in severe allergic asthma. Allergy 2018, 73, 2192-2204. [CrossRef] [PubMed]

47. Volpe, E.A.; Henriksson, J.T.; Wang, C.; Barbosa, F.L.; Zaheer, M.; Zhang, X.; Pflugfelder, S.C.; De Paiva, C.S. Interferon-gamma deficiency protects against aging-related goblet cell loss. Oncotarget 2016, 7, 64605-64614. [CrossRef]

48. Novaes, P.; Saldiva, P.H.D.N.; Kara-José, N.; Macchione, M.; Matsuda, M.; Racca, L.; Berra, A. Ambient levels of air pollution induce goblet-cell hyperplasia in human conjunctival epithelium. Environ. Health Perspect. 2007, 115, 1753-1756. [CrossRef]

49. Dartt, D.A. Control of mucin production by ocular surface epithelial cells. Exp. Eye Res. 2004, 78, $173-185$. [CrossRef]

50. Kondo, M.; Tamaoki, J.; Takeyama, K.; Nakata, J.; Nagai, A. Interleukin-13 induces goblet cell differentiation in primary cell culture from guinea pig tracheal epithelium. Am. J. Respir. Cell Mol. Boil. 2002, 27, 536-541. [CrossRef]

(C) 2020 by the authors. Licensee MDPI, Basel, Switzerland. This article is an open access article distributed under the terms and conditions of the Creative Commons Attribution (CC BY) license (http://creativecommons.org/licenses/by/4.0/). 